\title{
Article \\ Identification and Application of Bioactive Compounds from Garcinia xanthochymus Hook. for Weed Management
}

\author{
Md. Mahfuzur Rob ${ }^{1,2,3}{ }^{\oplus}$, Kawsar Hossen ${ }^{1,3}{ }^{\oplus}$, Mst. Rokeya Khatun ${ }^{1,3}$, Keitaro Iwasaki ${ }^{4}$, Arihiro Iwasaki ${ }^{4}{ }^{\circ}$, \\ Kiyotake Suenaga ${ }^{4}(\mathbb{D}$ and Hisashi Kato-Noguchi $1,3, * \mathbb{C}$ \\ 1 Department of Applied Biological Science, Faculty of Agriculture, Miki, Kagawa University, \\ Kagawa 761-0795, Japan; mahfuzrob.hor!@sau.ac.bd (M.M.R.); kawsar.ag@nstu.edu.bd (K.H.); \\ rokeya.entom@bau.edu.bd (M.R.K.) \\ 2 Department of Horticulture, Faculty of Agriculture, Sylhet Agricultural University, Sylhet 3100, Bangladesh \\ 3 The United Graduate School of Agricultural Sciences, Ehime University, 3-5-7 Tarumi, Matsuyama, \\ Ehime 790-8566, Japan \\ 4 Department of Chemistry, Faculty of Science and Technology, Keio University, 3-14-1 Hiyoshi, Kohoku, \\ Yokohama 223-8522, Japan; keitalo@keio.jp (K.I.); a.iwasaki@chem.keio.ac.jp (A.I.); \\ suenaga@chem.keio.ac.jp (K.S.) \\ * Correspondence: kato.hisashi@kagawa-u.ac.jp
}

\section{check for} updates

Citation: Rob, M..M.; Hossen, K.; Khatun, M..R.; Iwasaki, K.; Iwasaki, A.; Suenaga, K.; Kato-Noguchi, H. Identification and Application of Bioactive Compounds from Garcinia xanthochymus Hook. for Weed Management. Appl. Sci. 2021, 11, 2264. https://doi.org/10.3390/ app11052264

Academic Editors: Ana M. L. Seca and Eugenia Gallardo

Received: 1 February 2021

Accepted: 28 February 2021

Published: 4 March 2021

Publisher's Note: MDPI stays neutral with regard to jurisdictional claims in published maps and institutional affiliations.

Copyright: (c) 2021 by the authors. Licensee MDPI, Basel, Switzerland. This article is an open access article distributed under the terms and conditions of the Creative Commons Attribution (CC BY) license (https:/ / creativecommons.org/licenses/by/ $4.0 /)$.

\begin{abstract}
The allelopathic potential of plant species and their related compounds has been increasingly reported to be biological tools for weed control. The allelopathic potential of Garcinia xanthochymus was assessed against several test plant species: lettuce, rapeseed, Italian ryegrass, and timothy. The extracts of G. xanthochymus leaves significantly inhibited all the test plants in a concentration- and species-specific manner. Therefore, to identify the specific compounds involved in the allelopathic activity of the G. xanthochymus extracts, assay-guided purification was carried out and two allelopathic compounds were isolated and identified as methyl phloretate \{3-(4-hydroxyphenyl) propionic acid methyl ester\} and vanillic acid (4-hydroxy-3-methoxybenzoic acid). Both of the substances significantly arrested the cress and timothy seedlings growth. $I_{50}$ values (concentrations required for $50 \%$ inhibition) for shoots and roots growth of the cress and timothy were 113.6-104.6 and 53.3-40.5 $\mu \mathrm{M}$, respectively, for methyl phloretate, and 331.6-314.7 and 118.8-107.4 $\mu \mathrm{M}$, respectively, for vanillic acid, which implied that methyl phloretate was close to 3 - and 2-fold more effective than vanillic acid against cress and timothy, respectively. This report is the first on the presence of methyl phloretate in a plant and its phytotoxic property. These observations suggest that methyl phloretate and vanillic acid might participate in the phytotoxicity of G. xanthochymus extract.
\end{abstract}

Keywords: Garcinia xanthochymus; growth inhibitory compounds; allelopathy; vanillic acid; methyl phloretate

\section{Introduction}

With the world population increasing, maximizing agricultural production is essential. Weeds constrain agricultural production by directly competing with crops for growth resources [1]. Using synthetic herbicides may be the most efficient and cost-effective weed management strategy that has contributed to improving crop production over the last few decades [2]. However, non-judicious use of synthetic agrochemicals has had a significant negative effect on the planet and human wellbeing [3]. The evolution of resistant weeds is another consequence of extensive herbicide use [4]. Thus, to achieve safer agriculture, it is essential to replace hazardous synthetic herbicides with eco-friendly weed-management approaches. Natural compounds with diversified structures and modes of action could offer a new way to develop natural bio-herbicides [5]. Plants produce secondary metabolites called allelochemicals, which can negatively influence the process of growth, and development of surrounding plants [6,7]. In recent years, plant-derived 
natural phytotoxic compounds have been broadly investigated for herbicidal properties and have been shown to suppress weeds. These compounds can then be used as promising templates for standard bio-herbicides [8].

Garcinia xanthochymus Hook. f. ex T. Anderson (Clusiaceae) is a medium-size tree that has straight trunk with spreading type branches rising in a whorl [9]. This plant is generally found in Bangladesh, India, Myanmar, Thailand, and China [10,11]. G. xanthochymus is popularly known as false mangosteen because the shape of its fruit is similar to that of mangosteen. The leaves of the plant are light green color during young stage and become dark green when mature [12]. Distinct parts of this tree have traditionally been used for different therapeutic practices for many years in different south Asian countries [13]. In Bangladesh, G. xanthochymus is usually treated as folk drug for the treatment of diarrhea, dysentery, and vomiting. This plant is also used to treat worms and food toxins [14].

Earlier reports revealed that G. xanthochymus contains several phytochemicals that have antibacterial, anti-inflammatory, and antioxidant activities [15]. Although extensive research on different biological activities of G. xanthochymus have been conducted, very little is known about its phytotoxic potential or the constituents responsible for its phytotoxicity. Hence, this study aimed to (i) examine the phytotoxic potential of G. xanthochymus and (ii) detect phytotoxic substances which can be used as a potential candidate for bioherbicide.

\section{Materials and Methods}

\subsection{Plant Sample}

The leaf samples of Garcinia xanthochymus Hook.f. ex T.Anderson were obtained from a North-Eastern district (Netrokona) of Bangladesh $\left(24.8750^{\circ} \mathrm{N} 90.7333^{\circ} \mathrm{E}\right.$ ) in the time of June and July 2017. A voucher specimen (SAUCB 19127) was submitted to the Crop Botany Herbarium at Sylhet Agricultural University, Sylhet-3100, Bangladesh. Collected leaves were thoroughly washed and dried under room temperature. Then, the leaves were powdered in a grinder and kept for further use at $2{ }^{\circ} \mathrm{C}$.

\subsection{Model Test Species}

Four model test plant species Italian ryegrass (Lolium multiflorum Lam.), lettuce (Lactuca sativa L.), rapeseed (Brassica napus L.) and timothy (Phleum pratense L.) were chosen for conducting the phytotoxicity assay.

\subsection{Extraction and Bioassay}

In total, $100 \mathrm{~g}$ leaf powder of G. xanthochymus was extracted with $500 \mathrm{~mL}$ aqueous methanol $(70 \%(v / v))$ at room temperature for two days. After filtration with single layer filter paper (No. 2, $125 \mathrm{~mm}$; Toyo Ltd., Tokyo, Japan), the residue was re-extracted for one day with equal volume of methanol and filtered again. The two filtrates were then mixed and dried in a rotavapor at $40{ }^{\circ} \mathrm{C}$. The bioassay experiment was conducted with G. xanthochymus crude extracts against selected tested plants at different concentrations as $0.001,0.003,0.01,0.03,0.1$, and $0.3 \mathrm{~g}$ of dry weight (DW) equivalent extract $/ \mathrm{mL}$ as described by Rob et al. [16]. To prepare desired concentrates, an aliquot of the extracts was applied to a sheet of filter paper (No. 2) in $28 \mathrm{~mm}$ Petri dishes. Then, the solvent of the mixture (methanol) was dried in a draft chamber and $0.6 \mathrm{~mL}$ of $0.05 \%(v / v)$ aqueous Tween 20 (polyoxyethylene sorbitan monolaurate; Nacalai, Kyoto, Japan) solution was added to each Petri dish. Tween 20 was used as a non-toxic surfactant. Then, seeds of test plants were set. The seeds in the Petri dishes treated with Tween 20 without extract were used as a control.

\subsection{Purification of The Active Substances}

Powder of Garcinia xanthochymus leaves $(2 \mathrm{~kg}$ ) was extracted as aforementioned procedure. The obtained extracts were then evaporated with a vacuum evaporator at $40{ }^{\circ} \mathrm{C}$ to produce an aqueous residue and adjusted to $\mathrm{pH} 7.0$ with phosphate buffer (1M). This residue was partitioned with an equal volume of ethyl acetate for three times. The un- 
wanted aqueous part in ethyl acetate fraction was removed by adding anhydrous $\mathrm{Na}_{2} \mathrm{SO}_{4}$. As described above, a bioassay with the generated aqueous and ethyl acetate fractions was conducted against cress. The ethyl acetate fraction imposed stronger phytotoxic activity compared to the aqueous fraction (data not shown). Therefore, ethyl acetate fraction was selected for further bio-guided fractionation by different column chromatographic steps including silica gel, Sephadex LH-20, $\mathrm{C}_{18}$ cartridge and reverse-phase HPLC $(500 \times 10 \mathrm{~mm}$ I.D. ODS AQ-325; YMC Ltd., Kyoto, Japan) monitoring cress phytotoxicity assay in each purification step following the procedure described by Rob et al. (2019) which led to the isolation of two substances, 1 and 2. These substances 1 and 2 were then re-purified with reverse-phase HPLC $\left(4.6 \times 250 \mathrm{~mm}\right.$ I.D., S-5 $\mu \mathrm{m}$, Inertsil ${ }^{\circledR}$ ODS-3; GL Science Inc., Tokyo, Japan) at a flow rate of $0.8 \mathrm{~mL} \mathrm{~min}^{-1}$ with $5 \%$ and $30 \%$ aqueous methanol and obtained at 10-15 $\mathrm{min}$ and 50-60 min retention time, respectively. Finally, the two substances were characterized by spectral data analysis.

\subsection{Bioassay of the Isolated Compounds}

The identified compounds were dissolved in $2 \mathrm{~mL}$ methanol to make different concentrations $(1,3,10,30,100,300$, and $1000 \mu \mathrm{M})$. Then, prepared concentrations were applied on cress and timothy to perform bioassays described above.

\subsection{Statistical Analysis}

Bioassays were replicated thrice with 10 seedlings and repeated twice. The obtained data were subjected to ANOVA followed by Tukey's HSD test with the help of statistical software "SPSS" Version 24 [17]. Concentrations required for the suppression of 50\% growth of the tested plants ( $I_{50}$ value) in assay experiments were estimated by the logistic regression equation of the concentration-response curves.

\section{Results}

\subsection{Phytotoxic Activity of the G. Xanthochymus Extract}

The effect of aqueous methanolic extract obtained from G. xanthochymus is presented in Figure 1. All the applied concentrations suppressed the growth of all test plant species, except $0.001 \mathrm{~g}$ DW equivalent extract $\mathrm{mL}^{-1}$ concentration. At concentration $0.1 \mathrm{~g} \mathrm{DW}$ equivalent extract $\mathrm{mL}^{-1}$, lettuce growth was completely restricted while at the same treatment, shoot and root length of rapeseed, Italian ryegrass and timothy were restricted to $3.88,3.41,3.05 \%$ and $2.9,5.5,0.0 \%$ of control seedlings, respectively. The seedling length of all test plants limited to less than $3 \%$ of control, when treated with the concentration obtained from $0.3 \mathrm{~g}$ DW equivalent extract $\mathrm{mL}^{-1}$. The $I_{50}$ values of $G$. xanthochymus extract for all tested plants varied from 4.7 to $17.2 \mathrm{mg}$ DW equivalent extract $\mathrm{mL}^{-1}$ as shown in Table 1.

\subsection{Bioativity of Different Fractions in The Separtion Steps}

Different fractions in silica gel column chromatography showed different level of activity at the concentration $0.3 \mathrm{~g}$ dry weight equivalent extract $/ \mathrm{mL}$ of $\mathrm{G}$. xanthochymus. (Figure 2). The highest bioactivity was achieved with the fractions containing 60 and $70 \%$ ethyl acetate in n-hexane and inhibited the seedling growth of cress by less than 13 and $2 \%$, respectively. Combined crude of both of these fractions was subjected to separate expected bioactive compounds. In each step, the highest bioactive fraction was selected for the next separation steps (data not shown). 


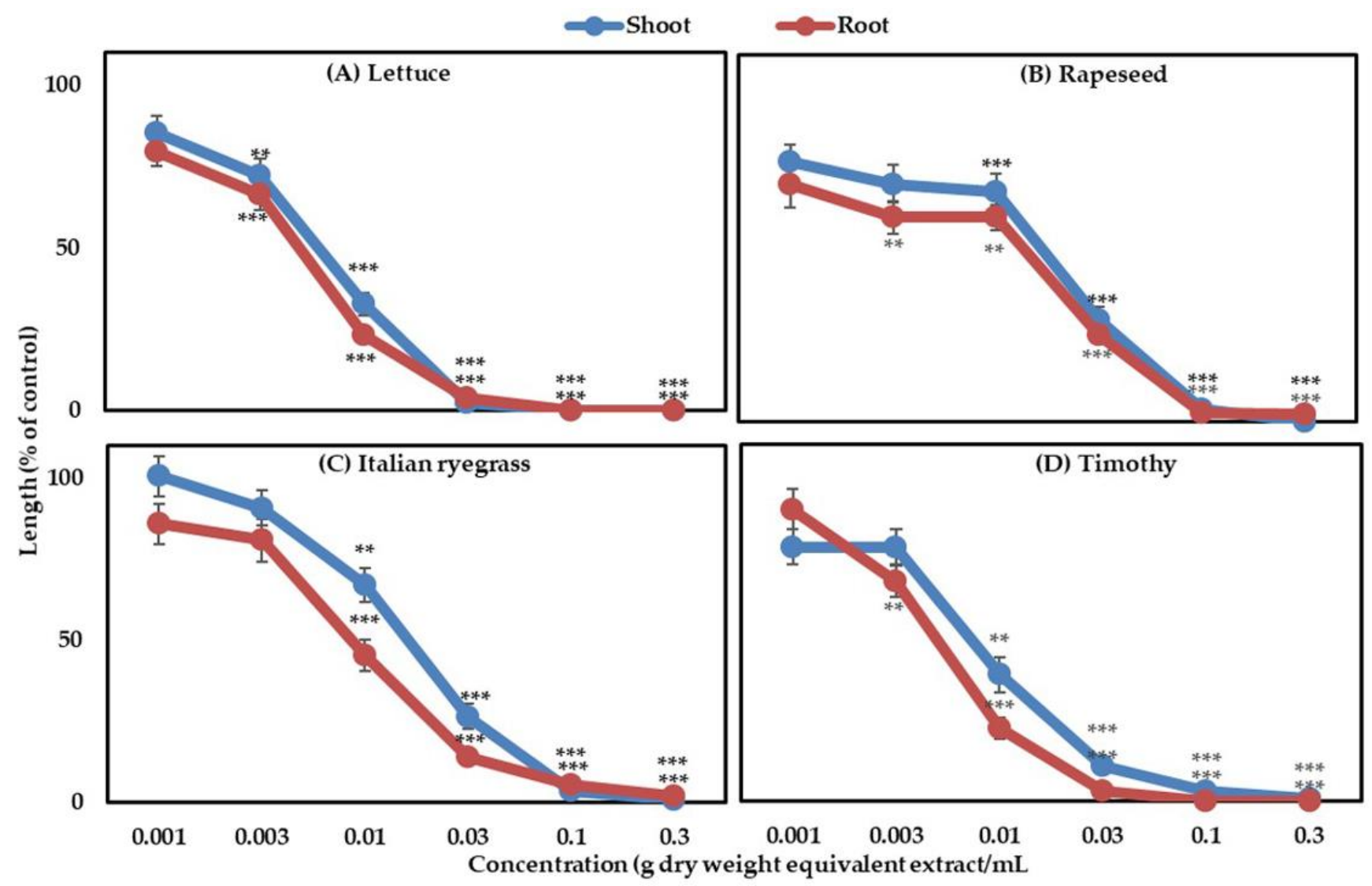

Figure 1. Effect of the G. xanthochymus extracts on the shoot and root growth of (A) lettuce, (B) rapeseed, (C) Italian ryegrass, and (D) timothy at different concentrations. Mean \pm SE was calculated from two independent experiments (Replication $=3$ times, number of seedlings $/$ treatments $=10, \mathrm{n}=60$ ). Asterisks denote significant variations between indicated plants $\left(^{* *} p<0.01\right.$ and $\left.{ }^{* * *} p<0.001\right)$.

Table 1. $I_{50}$ values (concentrations causing 50\% growth inhibition) of Garcinia xanthochymus leaf extracts (mg dry weight equivalent extract $/ \mathrm{mL}$ ) on lettuce, rapeseed, Italian ryegrass, and timothy \pm standard deviation.

\begin{tabular}{ccc}
\hline \multicolumn{2}{c}{ Aqueous Methanol Extracts of G. xanthochymus (mg Dry Weight Equivalent Extract/mL) } \\
\hline Test plant Species & Shoot & Root \\
\hline Lettuce & $7.13 \pm 0.94$ & $4.73 \pm 0.61$ \\
Rapeseed & $17.20 \pm 0.68$ & $14.23 \pm 0.85$ \\
Italian ryegrass & $15.84 \pm 0.78$ & $8.53 \pm 0.99$ \\
Timothy & $7.13 \pm 0.72$ & $4.81 \pm 0.97$ \\
\hline
\end{tabular}

\subsection{Characterization of The Compounds}

Two phytotoxic substances were identified by bio-guided fractionation from the leaf extract of $G$. xanthochymys by spectral analysis. The formula of the substance 1 was assigned as $\mathrm{C}_{8} \mathrm{H}_{8} \mathrm{O}_{4}$ based on HRESIMS at m/z 167.0349 [M-H]- (calcd for $\mathrm{C}_{8} \mathrm{H}_{7} \mathrm{O}_{4}$, 167.0344, $\Delta=+0.5 \mathrm{mmu}) ;{ }^{1} \mathrm{H} \mathrm{NMR}\left(400 \mathrm{MHz}, \mathrm{D}_{2} \mathrm{O}\right) \delta_{\mathrm{H}} 7.52(\mathrm{~d}, J=7.50 \mathrm{~Hz}, 1 \mathrm{H}, \mathrm{H}-2)$, $7.45(\mathrm{dd}, J=8.5,2.0 \mathrm{~Hz}, 1 \mathrm{H}, \mathrm{H}-6), 6.93(\mathrm{~d}, J=8.5 \mathrm{~Hz}, 1 \mathrm{H}, \mathrm{H}-5), 3.90$ (s, $3 \mathrm{H}, \mathrm{H}-8)$; ${ }^{13} \mathrm{C}$ NMR $\left(100 \mathrm{MHz}, \mathrm{D}_{2} \mathrm{O}\right) \delta_{\mathrm{C}} 173.5(\mathrm{C}-7), 147.9$ (C-4), 146.7 (C-3), 128.1 (C-6), 123.2 (C-1), 114.8 (C5), 113.1 (C-2), 55.8 (C-8). Comparing this spectral data with previously published data substance was recognized as vanillic acid with the systematic name 4-hydroxy-3-methoxy benzoic acid shown in Figure 3 [18]. 


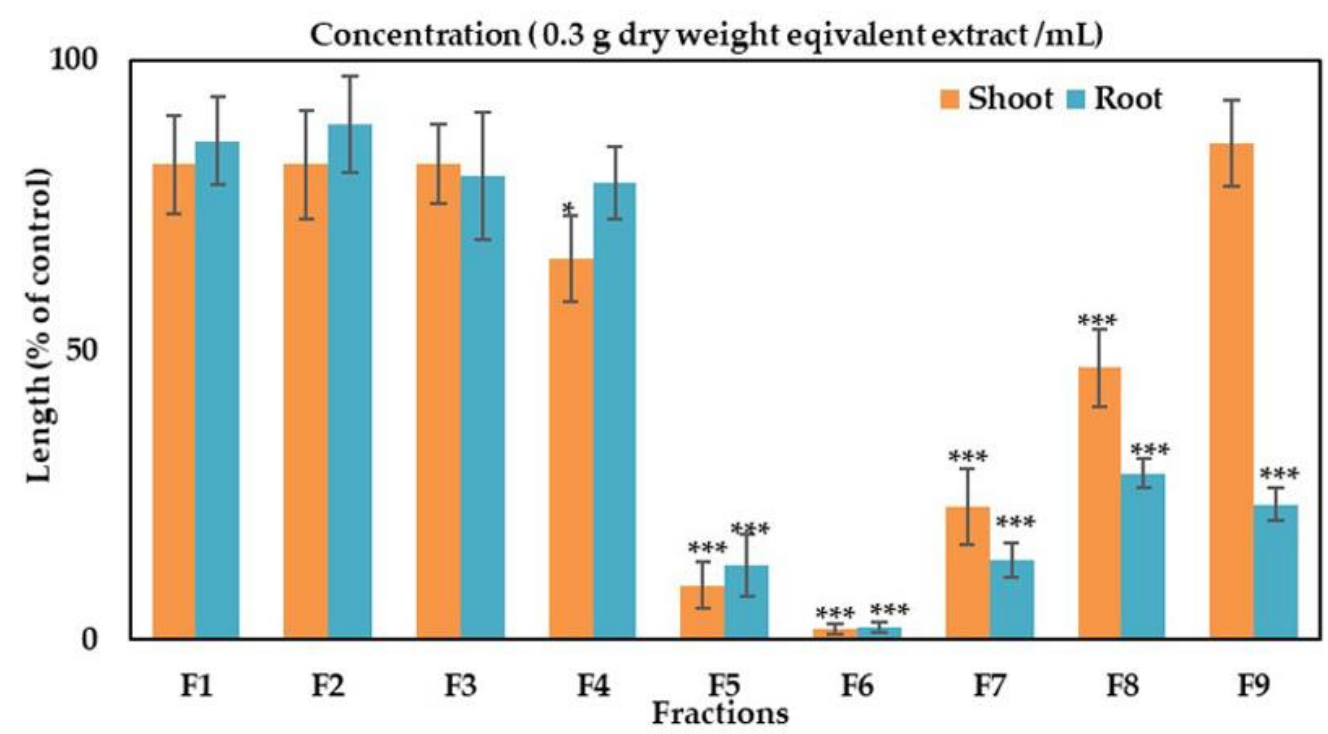

Figure 2. Effect of silica gel column fractions on the seedling growth of cress at the concentration $0.3 \mathrm{~g}$ dry weight equivalent extract/mL of G. xanthochymus. The column was eluted with raising quantities of the ethyl acetate $(10 \%$ per step, $v / v)$ in n-hexane: F1, F2, F3, F4, F5, F6 and F7 contained 20\%, 30\%, 40\%, 50\%, 60\%, 70\% and 80\% ethyl acetate in n-hexane, respectively, F8 (ethyl acetate), F9 (methanol). The values are mean \pm SE obtained from two independent experiments. Error bars are standard error of the mean. Asterisks show major variations between treatments and control by least significant difference (LSD) test ${ }^{*} p<0.05$ and $\left.{ }^{* *} p<0.001\right)$.<smiles>COc1cc(C(=O)O)ccc1O</smiles>

Vanillic Acid

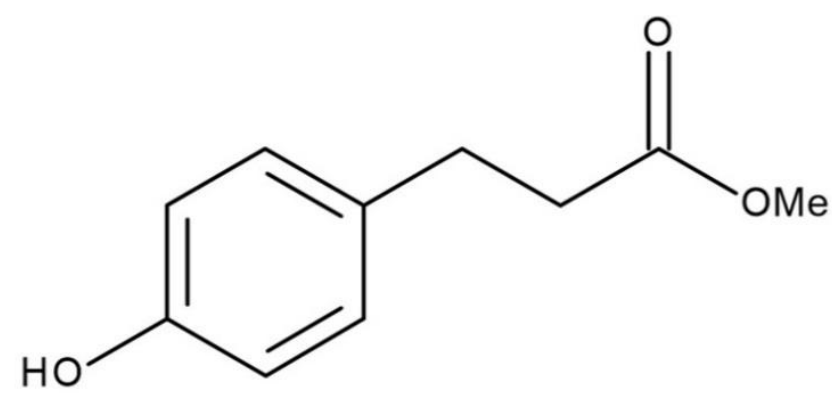

Methyl Phloretate

Figure 3. Molecular structure of the vanillic acid and the methyl phloretate from the G. xanthochymus leaf extract.

The molecular formula of the substance 2 was assigned as $\mathrm{C}_{10} \mathrm{H}_{12} \mathrm{O}_{3}$ based on HRESIMS at $\mathrm{m} / \mathrm{z} 181.0830[\mathrm{M}+\mathrm{H}]^{+}$(calcd for $\mathrm{C}_{10} \mathrm{H}_{13} \mathrm{O}_{3}, 181.0865, \Delta=-3.5 \mathrm{mmu}$ ); ${ }^{1} \mathrm{H}$ NMR $\left(400 \mathrm{MHz}, \mathrm{CDCl}_{3}\right) \delta_{\mathrm{H}} 7.07(\mathrm{~d}, J=8.7 \mathrm{~Hz}, 2 \mathrm{H}, \mathrm{H} 5,9), 6.76(\mathrm{~d}, J=8.7 \mathrm{~Hz}, 2 \mathrm{H}, \mathrm{H6}, 8)$, $3.67(\mathrm{~s}, 3 \mathrm{H}, \mathrm{H} 10), 2.88(\mathrm{t}, J=7.8 \mathrm{~Hz}, 2 \mathrm{H}, \mathrm{H} 3), 2.60(\mathrm{t}, J=7.8 \mathrm{~Hz}, 2 \mathrm{H}, \mathrm{H} 2)$. The substance was identified as methyl phloretate \{3-(4-hydroxyphenyl) propionic acid methyl ester\} (Figure 3) by investigating original data with previously documented literature [19].

\subsection{Biological Activity of the Isolated Substances}

The phytotoxic activity of two identified substances was checked on cress and timothy. Vanillic acid caused significant inhibition on growth of cress and timothy at concentrations 30 and $10 \mu \mathrm{M}$, respectively (Figure 4). The $I_{50}$ values of vanillic acid for the shoot and root growth of cress were 331.7 and $314.7 \mu \mathrm{M}$, respectively, while those values for timothy were 118.8 and $107.3 \mu \mathrm{M}$, respectively (Table 2). Similarly, methyl phloretate also possessed strong phytotoxicity against the test plants with the $I_{50}$ values ranged from 104.7 to $113.7 \mu \mathrm{M}$ for cress seedlings and 53.4 to $40.6 \mu \mathrm{M}$ for timothy seedlings (Table 2). It is notable that, the inhibition was concentration dependent and timothy was more susceptible to both 
compounds compared to cress. Moreover, methyl phloretate was more phytotoxic than vanillic acid concerning the $I_{50}$ values of the compounds (Figure 4).
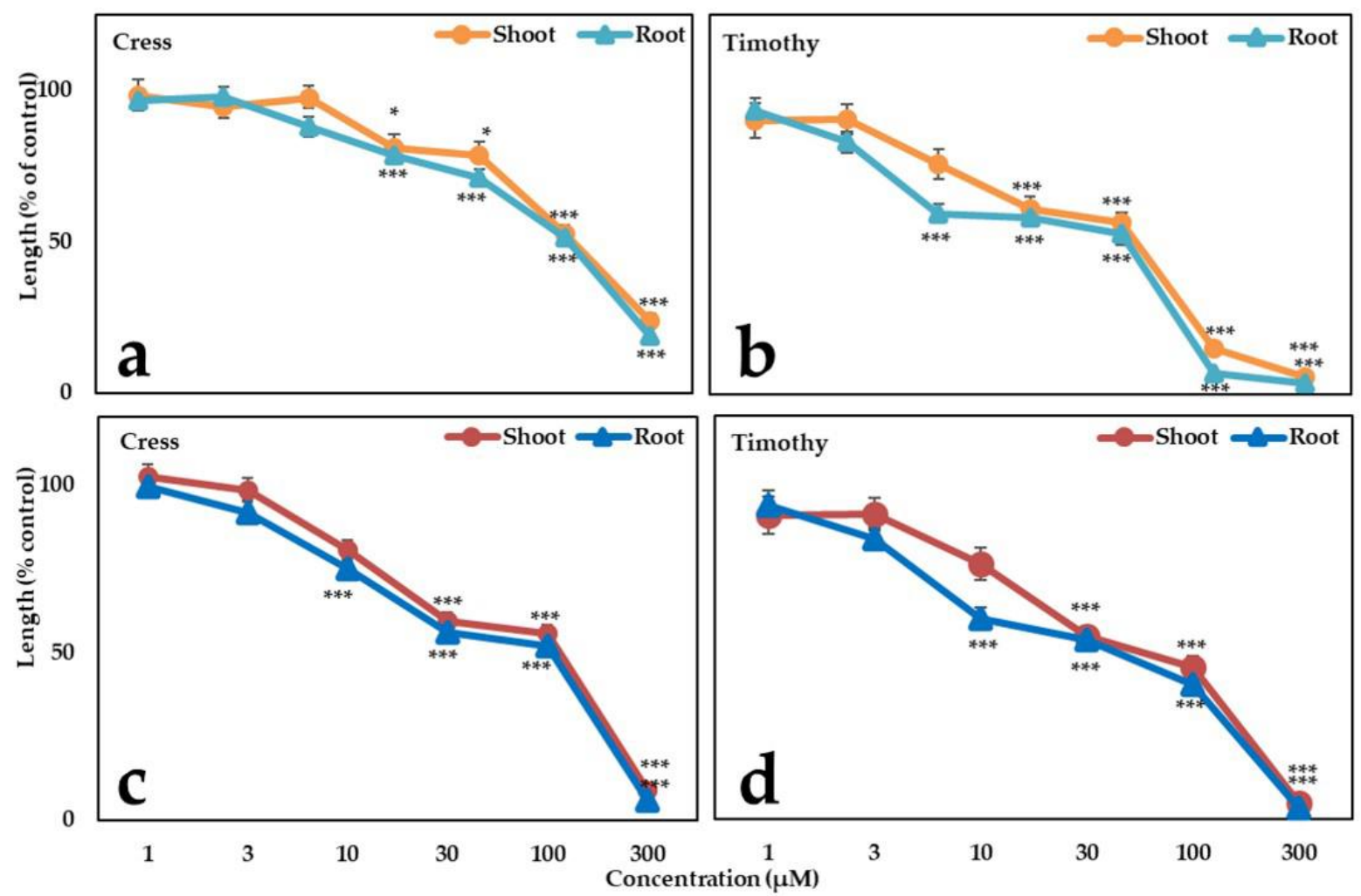

Figure 4. Effects of the vanillic acid $(\mathbf{a}, \mathbf{b})$ and methyl phloretate $(\mathbf{c}, \mathbf{d})$ on cress and timothy. Values represent means $\pm \mathrm{SE}$ from three replicates $(n=30)$. The significant variations between control and treatment are denoted by ${ }^{*} p<0.05$ and $* * * p<0.001$.

Table 2. The $I_{50}$ value (concentration causing $50 \%$ of growth inhibition) of vanillic acid and methyl phloretate $(\mu \mathrm{M})$ on cress and timothy standard deviation.

\begin{tabular}{|c|c|c|c|c|c|}
\hline \multirow{2}{*}{\multicolumn{2}{|c|}{ Tested Species }} & \multicolumn{2}{|c|}{ Vanillic Acid } & \multicolumn{2}{|c|}{ Methyl Phloretate } \\
\hline & & Shoot $* * *$ & $\operatorname{Root} * * *$ & Shoot $* * *$ & $\operatorname{Root} * * *$ \\
\hline dicot & Cress & $331.7 \pm 7.1$ & $314.7 \pm 8.3$ & $113.7 \pm 3.8$ & $104.7 \pm 2.9$ \\
\hline Monocot & Timothy & $118.8 \pm 4.4$ & $107.3 \pm 4.1$ & $53.4 \pm 2.8$ & $40.6 \pm 1.9$ \\
\hline
\end{tabular}

\section{Discussion}

The results revealed that G. xanthochymus extract markedly inhibited both the dicot species (lettuce and rapeseed) and the monocot species (Italian ryegrass and timothy). The phytotoxicity of the extract against all the test plants increased with the increase in concentration. Other researchers have also documented such concentration-dependent inhibitory activity of different plant extracts [20-26]. Our previous experiment with Garcinia pedunculata also showed strong inhibition against several test species [27]. In addition, the phytotoxic activity of the extracts varied against different test plants. Tuyen et al. [28] also reported species specificity of Castanea crenata extracts against radish, lettuce, and barnyard grass. These concentration-dependent and species-specific phytotoxicity of the $G$. xanthochymus leaf extract led us to assume that the extract contains potential phytotoxic substances.

Bio-guided isolation resulted in obtaining two phytotoxic substances from the G. xanthochymus leaf extract, which were identified as vanillic acid, and methyl phloretate through 
spectral analysis. Vanillic acid is one of the most common phenolic compounds found in different plant parts. It was previously identified in extracts from different plants such as Alnus japonica, Gossypium mexicanum, Rosa canina, Panax ginseng [29], and Chenopodium murale [30]. Vanillic acid can act as an antimicrobial, antioxidant [31], anti-inflammatory, and antidiabetic agent [32]. However, phytotoxic effects of the vanillic acid have also been narrated by many researchers [33]. Methyl phloretate is a methyl ester of phenylpropanoid phenol, phloretic acid [34], which is a naturally occurring phenolic compound that can be obtained from $p$-coumaric acid hydrogenation or synthesized from phloretin, a secondary metabolite of apple leaves [35]. In phloretic acid, there is a propionic acid side chain that is suitable for esterification, leading to production of methyl phloretate [36]. Methyl phloretate is a potential synthetic intermediate and can be used to prepare antidiabetic agents [37].

In our study, the inhibitory activity of vanillic acid and methyl phloretate depended on the concentration and species. In previous reports such inhibitory activities were noted from different phytotoxic substances [20,38]. Piyatida et al. reported that vanillic acid has strong growth-inhibitory activity against cress and timothy, and the inhibition is more pronounced against timothy than cress [39]. This species specificity of allelochemicals might be because of different physical and physiological features of receptor seeds including thickness of seed coat, cell membrane permeability, and sensitive enzymes in seeds [40]. In our experiment, timothy was much more affected by both the allelochemicals compared with cress. Our finding is in line with that by Pèrez et al. [41], who reported that small-seeded tested plants were usually more susceptible to phytochemicals, because the concentration of the phytochemicals necessary to produce suppression is influenced by seed size. Taking into consideration the 1000 seed weight, the weight of timothy is around 5-times lower than cress, which is why timothy is more sensitive to the allelochemicals $[42,43]$.

The data from our experiment also revealed that methyl phloretate has much more inhibitory activity than vanillic acid against tested plant species. The allelochemicals affect plant growth through different chemical reactions. The toxicity of phytochemicals is regulated by the various functional groups in the structure of compound, which act on different positions of the enzymes, and affect their activity [40,44]. Vanillic acid is a mono hydroxy benzoic acid with one methoxy group in its aromatic ring. Maffei et al. [45] reported that the methoxy groups on benzoic acid ring increase the phytotoxicity, whereas the hydroxy groups decrease the phytotoxicity of benzoic acid derivatives in cucumber seed germination and early growth. Maffei et al. [45] also showed that the hydroxy group in the $\mathrm{C} 4$ position scavenges the inhibitory action of the methoxy group in vanillic acid. Levi-Minzi et al. [46] showed that 4-hydroxy-3-methoxy benzoic acid is much more phytotoxic against wheat growth compared with 4-hydroxy benzoic acid. We therefore conclude that the methoxy group in the $\mathrm{C}-3$ position contributes to the phytotoxicity of vanillic acid.

On the other hand, methyl phloretate is a monohydroxy derivative of cinnamic acids. With cinnamic acid derivatives, the more hydroxyl groups in its benzene ring the less the phytotoxicity [47]. Therefore, a single hydroxyl group in benzene ring of methyl phloretate may influence its phytotoxic potential. In addition, some researchers proposed that the hydrophobicity of the compound corresponds with higher toxicity in case of cinnamic acid derivatives [48,49]. Hydrophobic compounds bearing lipophilic properties make them capable of passing through the cell membrane more readily [50]. Some researchers reported that the methyl ester of cinnamic acid derivatives has higher growth-inhibitory activity corresponding to their free acids because esterification of the carboxyl group results in more hydrophobic compounds having more phytotoxic potential [51,52]. Accordingly, esterification of phloretic acid (corresponding free phenolic acid of methyl phloretate) which is already documented to have growth-inhibitory activity, might lead to producing more phytotoxic methyl phloretate. Waśko et al. [52] showed that the allelopathic activity of methyl p-coumarate, which has a similar structure to methyl phloretate, was more inhibitory than its corresponding free phenolic acid, p-coumaric acid. 
In general, cinnamic acid derivatives are more phytotoxic than benzoic acid derivatives due to their higher hydrophobicity $[47,53]$. Our results corroborate this finding because the more phytotoxic methyl phloretate is a derivative of cinnamic acids, while the less phytotoxic vanillic acid is a derivative of benzoic acid.

\section{Conclusions}

The aqueous methanol extract of G. xanthochymus significantly inhibited four test plant species, lettuce, rapeseed, Italian ryegrass, and timothy. Generally, leaves of G. xanthochymus are not consumed and are classified as waste material. However, from our experiment, it is evident that leaves of G. xanthochymus have the potential to be used to manage weeds. Two identified substances, vanillic acid and methyl phloretate, isolated from the G. xanthochymus leaf extract imposed significant growth inhibitory activity on cress and timothy. Methyl phloretate had around two- and three-fold higher inhibitory activity against timothy and cress, respectively, compared with vanillic acid. This report is the first on the existence of methyl phloretate in a plant. Therefore, field experiments could determine the potential of the crude extract of G. xanthochymus and methyl phloretate it contains as a biological agent to control weeds in an eco-friendly way.

Author Contributions: Conceptualization, M.M.R., and H.K.-N.; methodology, M.M.R., K.H., M.R.K., K.S., A.I., K.I., and H.K-N; software, M.M.R., and K.H.; validation, K.S., K.I., A.I., and H.K.-N.; formal analysis, M.M.R., and K.H.; investigation, M.M.R., and K.H.; resources, H.K.-N.; data curation, H.K.N.; writing—original draft preparation, M.M.R., and K.H.; writing—review and editing, H.K.-N.; visualization, M.M.R., and K.H.; supervision, H.K.-N. All the authors have read and agreed with the manuscript. All authors have read and agreed to the published version of the manuscript.

Funding: This research work was supported through a MEXT scholarship (Grant Number MEXT193490) from the Japan government to conduct the study in Japan.

Institutional Review Board Statement: Not applicable

Informed Consent Statement: Not applicable

Acknowledgments: We thankful to the Government of Japan (MEXT scholarship, Grant number: MEXT-173591) to carry out this research work. We also express gratitude to Professor Dennis Murphy, for editing the English of this manuscript.

Conflicts of Interest: There was no conflict of interest declared by the authors.

\section{References}

1. Colbach, N.; Darmency, H.; Fernier, A.; Granger, S.; Corre, V.L.; Messéan, A. Simulating changes in cropping practices in conventional and glyphosate-resistant maize. II. Weed impacts on crop production and biodiversity. Environ. Sci. Pollut. Res. 2017, 24, 13121-13135. [CrossRef] [PubMed]

2. Feng, G.; Chen, M.; Ye, H.C.; Zhang, Z.K.; Li, H.; Chen, L.L.; Zhang, J. Herbicidal activities of compounds isolated from the medicinal plant Piper sarmentosum. Ind. Crops Prod. 2019, 132, 41-47. [CrossRef]

3. Magnoli, K.; Carranza, C.S.; Aluffi, M.E.; Magnoli, C.E.; Barberis, C.L. Herbicides based on 2, 4-D: Its behavior in agricultural environments and microbial biodegradation aspects. A review. Environ. Sci. Pollut. Res. Int. 2020, 27, 38501-38512. [CrossRef]

4. Moss, S.; Ulber, L.; Hoed, I.D. A herbicide resistance risk matrix. Crop Prot. 2019, 115, 13-19. [CrossRef]

5. Hossain, M.M. Recent perspective of herbicide: Review of demand and adoption in world agriculture. J. Bangladesh Agric. Univ. 2015, 13, 13-24. [CrossRef]

6. Arroyo, A.I.; Pueyo, Y.; Pellissier, F.; Ramos, J.; Espinosa-Ruiz, A.; Millery, A.; Alados, C.L. Phytotoxic effects of volatile and water-soluble chemicals of Artemisia herba-alba. J. Arid Environ. 2018, 151, 1-8. [CrossRef]

7. Rice, E.L. Allelopathy; Academic Press: Orlando, FL, USA, 1984.

8. Duke, S.O.; Dayan, F.E.; Romagni, J.G.; Rimando, A.M. Natural products as sources of herbicides: Current status and future trends. Weed Res. 2000, 40, 99-111. [CrossRef]

9. Hooker, J.D. The Flora of British India; L. Reeve and Co.: London, UK, 1874.

10. Verheij, E.W.M.; Coronel, R.E. Edible fruits and nuts. In Plant Resources of South-East Asia (PROSEA); Backhuys Publishers: Kerkwerve, The Netherlands, 1991; p. 175.

11. Zhong, F.F.; Chen, Y.; Song, F.J.; Yang, G.Z. Three new xanthones from Garcinia xanthochymus. Acta Pharm. Sinica. 2008, 43, 938-941.

12. Joseph, K.S.; Dandin, V.S.; Hosakatte, N.M. Chemistry and biological activity of Garcinia xanthochymus: A review. J. Biol. Act. Prod. Nat. 2016, 6, 173-194. [CrossRef] 
13. Perry, L.M.; Metzger, J. Medicinal Plants of East and Southeast Asia: Attributed Properties and Uses; MIT Press: Cambridge, MA, USA, 1980.

14. Trisuwan, K.; Boonyaketgoson, S.; Rukachaisirikul, V.; Phongpaichit, S. Oxygenated xanthones and bioflavonoids from the twigs of Garcinia xanthochymus. Tetrahedron Lett. 2014, 55, 3600-3602. [CrossRef]

15. Hassan, N.K.N.C.; Taher, M.; Susanti, D. Phytochemical constituents and pharmacological properties of Garcinia xanthochymusA review. Biomed. Pharmacother. 2018, 106, 1378-1389. [CrossRef]

16. Rob, M.M.; Hossen, K.; Iwasaki, A.; Suenaga, K.; Kato-Noguchi, H. Phytotoxic activity and identification of phytotoxic substances from Schumannianthus dichotomus. Plants 2020, 9, 102. [CrossRef] [PubMed]

17. IBM, Corp. IBM SPSS Statistics for Windows; Version 16.0; IBM Corp: Armonk, NY, USA, 2016.

18. Stalin, T.; Rajendiran, N. A study on the spectroscopy and photophysics of 4-hydroxy-3-methoxybenzoic acid in different solvents, $\mathrm{pH}$ and $\beta$-cyclodextrin. J. Mol. Struct. 2006, 794, 35-45. [CrossRef]

19. Clough, J.M.; Jones, R.V.; McCann, H.; Morris, D.J.; Wills, M. Synthesis and hydrolysis studies of a peptide containing the reactive triad of serine proteases with an associated linker to a dye on a solid phase support. Org. Biomol. Chem. 2003, 1, $1486-1497$. [CrossRef] [PubMed]

20. Bari, I.N.; Kato-Noguchi, H. Phytotoxic effect of Filicium decipiens leaf extract. Am. Eurasian J. Agric. Environ. Sci. 2017, 17, 288-292. [CrossRef]

21. Islam, M.S.; Iwasaki, A.; Suenaga, K.; Kato-Noguchi, H. 2-Methoxystypandrone, a potent phytotoxic substance in Rumex maritimus L. Theor. Exp. Plant Physiol. 2017, 29, 195-202. [CrossRef]

22. Islam, M.S.; Zaman, F.; Iwasaki, A.; Suenaga, K.; Kato-Noguchi, H. Phytotoxic potential of Chrysopogon aciculatus (Retz.) Trin. (Poaceae). Weed Biol. Manag. 2019, 19, 51-58. [CrossRef]

23. Hossen, K.; Das, K.R.; Okada, S.; Iwasaki, A.; Suenaga, K.; Kato-Noguchi, H. Allelopathic potential and active substances from Wedelia chinensis (Osbeck). Foods 2020, 9, 1591. [CrossRef]

24. Hossen, K.; Kato-Noguchi, H. Determination of allelopathic properties of Acacia catechu (L.f.) Willd. Not. Bot. Horti Agrobot. Cluj Napoca 2020, 48, 2050-2059. [CrossRef]

25. Zaman, F.; Iwasaki, A.; Suenaga, K.; Kato-Noguchi, H. Allelopathic potential and identification of two allelopathic substances in Eleocharis atropurpurea. Plant Biosys. 2020. [CrossRef]

26. Hossen, K.; Iwasaki, A.; Suenaga, K.; Kato-Noguchi, H. Phytotoxic Activity and Growth Inhibitory Substances from Albizia richardiana (Voigt.) King \& Prain. Appl. Sci. 2021, 11, 1455. [CrossRef]

27. Rob, M.M.; Kato-Noguchi, H. Study of the allelopathic activity of Garcinia pedunculata Roxb. Plant Omics. 2019, 12, 31-36. [CrossRef]

28. Tuyen, P.T.; Xuan, T.D.; Anh, T.T.T.; Van, T.M.; Ahmad, A.; Elzaawely, A.A.; Khanh, T.D. Weed suppressing potential and isolation of potent plant growth inhibitors from Castanea crenata Sieb. et Zucc. Molecules 2018, 23, 345. [CrossRef]

29. Khadem, S.; Marles, R.J. Monocyclic phenolic acids; hydroxy-and polyhydroxybenzoic acids: Occurrence and recent bioactivity studies. Molecules 2010, 15, 7985-8005. [CrossRef]

30. Batish, D.R.; Lavanya, K.; Pal, H.S.; Kohli, R.K. Root-mediated allelopathic interference of nettle-leaved goosefoot (Chenopodium murale) on wheat (Triticum aestivum). J. Agron. Crop. Sci. 2007, 193, 37-44. [CrossRef]

31. Kakkar, S.; Bais, S. A review on protocatechuic acid and its pharmacological potential. ISRN Pharmacol. 2014, 1-9. [CrossRef]

32. Bai, F.; Fang, L.; Hu, H.; Yang, Y.; Feng, X.; Sun, D. Vanillic acid mitigates the ovalbumin (OVA)-induced asthma in rat model through prevention of airway inflammation. Biosci. Biotechnol. Biochem. 2019, 83, 531-537. [CrossRef] [PubMed]

33. Zhang, T.-T.; Zheng, C.-Y.; Hu, W.; Xu, W.-W.; Wang, H.-F. The allelopathy and allelopathic mechanism of phenolic acids on toxic Microcystis aeruginosa. J. Appl. Phycol. 2010, 22, 71-77. [CrossRef]

34. Comi, M.; Lligadas, G.; Ronda, J.C.; Galia, M.; Cadiz, V. Renewable benzoxazine monomers from "lignin-like" naturally occurring phenolic derivatives. J. Polym. Sci. Part A Polym. Chem. 2013, 51, 4894-4903. [CrossRef]

35. Picinelli, A.; Dapena, E.; Mangas, J.J. Polyphenolic pattern in apple tree leaves in relation to scab resistance. A preliminary study. J. Agric. Food Chem. 1995, 43, 2273-2278. [CrossRef]

36. Trejo-Machin, A.; Verge, P.; Puchot, L.; Quintana, R. Phloretic acid as an alternative to the phenolation of aliphatic hydroxyls for the elaboration of polybenzoxazine. Green Chem. 2017, 19, 5065-5073. [CrossRef]

37. Sasaki, S.; Kitamura, S.; Negoro, N.; Suzuki, M.; Tsujihata, Y.; Suzuki, N.; Kobayashi, M. Design, synthesis, and biological activity of potent and orally available G protein-coupled receptor 40 agonists. J. Med. Chem. 2011, 54, 1365. [CrossRef]

38. Suzuki, M.; Chozin, M.A.; Iwasaki, A.; Suenaga, K.; Kato-Noguchi, H. Phytotoxic activity of Chinese violet (Asystasia gangetica (L.) T. Anderson) and two phytotoxic substances. Weed Biol. Manag. 2019, 19, 3-8. [CrossRef]

39. Piyatida, P.; Suenaga, K.; Kato-Noguchi, H. Allelopathic potential and chemical composition of Rhinacanthus nasutus extracts. Allelopath. J. 2010, 26, 207-216.

40. Macias, F.A.; Galindo, J.C.G.; Massanet, G.M. Potentials allelopathic activity of several sesquiterpene lactone models. Phytochemistry 1992, 31, 1969-1977. [CrossRef]

41. Pèrez, F.J. Allelopathic effect of hydroxamic acids from cereals on Avena sativa and A. fatua. Phytochemistry 1990, 29, 773-776. [CrossRef]

42. Stanisavljevic, R.; Đjokic, D.; Milenkovic, J.; Đukanovic, L.; Stevovic, V.; Simic, A.; Dodig, D. Seed germination and seedling vigour of Italian ryegrass, cocksfoot and timothy following harvest and storage. Cienc. Agrotec. 2011, 35, 1141-1148. [CrossRef] 
43. Shehzad, M.; Tanveer, A.; Ayub, M.; Mubeen, K.; Sarwar, N.; Ibrahim, M.; Qadir, I. Effect of weed-crop competition on growth and yield of garden cress (Lepidium sativum L.). J. Med. Plants Res. 2011, 5, 6169-6172. [CrossRef]

44. Sanchez-Maldonado, A.F.; Schieber, A.; Ganzle, M.G. Structure-function relationships of the antibacterial activity of phenolic acids and their metabolism by lactic acid bacteria. J. Appl. Microbiol. 2011, 111, 1176-1184. [CrossRef]

45. Maffei, M.; Bertea, C.M.; Garneri, F.; Scannerini, S. Effect of benzoic acid hydroxy-and methoxy-ring substituents during cucumber (Cucumis sativus L.) germination. I. Isocitrate lyase and catalase activity. Plant Sci. 1999, 141, 139-147. [CrossRef]

46. Levi-Minzi, R.; Saviozzi, A.; Riffaldi, R. Organic acids as seed germination inhibitors. J. Environ. Sci. Health 1994, $29,2203-2217$. [CrossRef]

47. Pinho, I.A.; Lopes, D.V.; Martins, R.C.; Quina, M.J. Phytotoxicity assessment of olive mill solid wastes and the influence of phenolic compounds. Chemosphere 2017, 185, 258-267. [CrossRef] [PubMed]

48. Wang, X.; Dong, Y.; Xu, S.; Wang, L.; Han, S. Quantitative structure-activity relationships for the toxicity to the tadpole Rana japonica of selected phenols. Bull. Environ. Contam. Toxicol. 2000, 64, 859-865. [CrossRef]

49. Wang, X.; Yu, J.; Wang, Y.; Wang, L. Mechanism-based quantitative structure-activity relationships for the inhibition of substituted phenols on germination rate of Cucumis sativus. Chemosphere 2002, 46, 241-250. [CrossRef]

50. Jităreanu, A.; Tătărîngă, G.; Zbancioc, A.M.; Stănescu, U. Toxicity of some cinnamic acid derivatives to common bean (Phaseolus vulgaris). Not. Bot. Horti. Agrobo. 2011, 39, 130-134. [CrossRef]

51. Guzman, J.D. Natural cinnamic acids, synthetic derivatives and hybrids with antimicrobial activity. Molecules 2014, 19, 19292-19349. [CrossRef]

52. Waśko, A.; Szwajgier, D.; Polak-Berecka, M. The role of ferulic acid esterase in the growth of Lactobacillus helveticus in the presence of phenolic acids and their derivatives. Eur. Food Res. Technol. 2014, 238, 299-306. [CrossRef]

53. Reynolds, T. Comparative effects of aromatic compounds on inhibition of lettuce fruit germination. Ann. Bot. 1978, 42, 419-427. [CrossRef] 